\title{
EXPERIMENTAL STUDY OF THE ANTIRACHITIC FACTOR IN HUMAN AND ANIMAL MILKS
}

BY

\author{
I. A. SABRI, M.R.C.P., D.T.M. \& H., \\ and
}

M. M. FIKRY, B.Sc., L.R.C.P., M.R.C.S.

(From the Pædiatric Department, Faculty of Medicine, Cairo.)

Rickets is a manifestation of disturbed nutrition, and as such must be intimately connected rtiologically with the diet of the child. This relationship between the diet and the disease has been the subject of many investigations since $\mathrm{Mellanby}^{1}$, in 1919, produced rickets in puppies by a deficient diet.

Milk, being the basic diet of every infant, was naturally the subject of many of these investigations. The anti-rachitic power of the various milks was a special point of interest. Practically all writers on this subject agree in considering human milk to be clinically a more powerful anti-rachitic agent than cow's and other animal milks used in infant feeding. Thus, Hess and Weinstock $^{2}$ showed that, in New York during the month of March, approximately all bottle-fed infants showed evidence of rickets, while only one-third to one-half of the breast-fed infants manifested signs of that disease.

In Egypt, where artificial feeding has not yet gained a strong foothold, and where natural feeding still predominates, rickets is a fairly common complaint among infants. Thus in Cairo, where more than 80 per cent. of infants are purely breast-fed, Shawki ${ }^{3}$ demonstrated that rickets affects practically 50 per cent. of infants between the ages of six months and two years. From the experimental point of view, however, the superiority of human milk over cow's milk as regards its vitamin-D content is not so definite. All workers consider both human and cow's milk to be poor in their vitamin-D content. Marriot ${ }^{4}$ states that there is on the average as much vitamin $\mathbf{D}$ in cow's milk as in human milk but none too much for the needs of the infant in either. Marfan" states that human milk contains little or no anti-rachitic factor, while cow's milk contains a little more of this factor.

Hess and Weinstock ${ }^{2}$ attribute this superiority in anti-rachitic power of human milk to the favourable equilibrium of the various ions that human milk contains, resulting in ccnditions which greatly further the absorption and the retention of calcium and phosphorus, and not to a higher content in human milk of the anti-rachitic factor. 


\section{Present investigations.}

Since the beginning of 1931 , we have been experimenting on the relation of milk to the ætiology of rickets, using for the purpose albino rats. These were chosen of an average age of four weeks and weight of $40 \mathrm{grm}$. from a stock bred in our laboratories for these experiments. The rachitogenic diet used is the Steenbock and Black diet No. 2,965, made up of yellow maize 76 per cent., gluten 20 per cent., calcium carbonate 3 per cent., and sodium chloride 1 per cent.

In most of our experiments, we used the preventive method. The rats were fed on the above rachitogenic diet plus the substance to be tested for a period of about four weeks, being kept all the time in a dark room. At the end of that period, the left knee-joints were radiographed, the animals killed and sections made from their joints examined microscopically. Phosphorus and calcium of the pooled blood of each group were also estimated in most of the experiments. Throughout every experiment, the rats were regularly weighed and their growth curves noted. Any rats that lost or did not gain weight properly were discarded. In reading the radiograms, the distance between the epiphysis and the diaphysis was measured in millimeters; a distance of less than $1 \mathrm{~mm}$. was considered as slight rickets, between 1 and $2 \mathrm{~mm}$. as moderate, and above $2 \mathrm{~mm}$. as marked rickets.

Experiments with whole milk.-An important point which should always be kept in mind in all experimental studies of rickets on rats is that these animals react towards the content of calcium and phosphorus in the diet differently from the human infant. Rats can absorb and assimilate these salts when given in appreciable quantities in their diet without any need for vitamin $\mathbf{D}$, while infants cannot do so unless the anti-rachitic factor is supplied as well ${ }^{2}$.

This fact is well exemplified in our first experiment (Table 1). In this experiment we found that human milk given to albino rats in per capita doses of $20 \mathrm{c.cm}$. had no effect in preventing rickets; while buffalo's milk (the milk commonly consumed in Egypt) in $10 \mathrm{c.cm}$. doses could definitely prevent the disease. In addition we could show, in the same experiment, that the mere addition of phosphates to the above tested rachitogenic diet could entirely prevent the development of rickets. The fat content in the amounts of milks given is equal, but the salt content of buffalo's milk is about five to six times that of human milk. Buffalo's milk contains an average of 7.5 per cent. fat and 0.75 per cent. salts.

The capacity of rats to absorb and utilize calcium and phosphorus salts without any accessory factor explains the stronger anti-rachitic power of buffalo's milk to rats.

Hess and Weinstock ${ }^{2}$, although using cow's milk and a different rachitogenic diet (No. 84, Sherman and Peppenheimer), came to conclusions very similar to our own. They required $20 \mathrm{c.cm}$. cow's milk to prevent 
rickets. Thus the difficulty of experimenting on rats with whole milk is quite evident. Yet, in spite of this difficulty, rats remain the best standard test animals we possess for assaying the potency of anti-rachitic substances. Various attempts have been made to overcome this salt factor. Outhouse, Macy and Brekke ${ }^{6}$ tried to eliminate this salt factor in experimental rickets by keeping the ratio $\mathrm{Ca} / \mathrm{P}$ constantly at 5 to 1 in all diets used; a ratio

TABLE 1.

Comparative anti-Rachitic value of human and of buffalo's milk.

\begin{tabular}{|c|c|c|c|}
\hline \multirow[t]{2}{*}{ Rats. } & \multirow[t]{2}{*}{ Diet (4 weeks). } & \multicolumn{2}{|c|}{ Rickets. } \\
\hline & & X-rays. & Microscope \\
\hline Group A. & Rachitogenic only & $\begin{array}{c}\text { Marked } \\
\text {," } \\
\text {," }\end{array}$ & $\begin{array}{c}\text { Marked } \\
\text { ", } \\
\text {," }\end{array}$ \\
\hline Group B. & Rachitogenic with $10 \mathrm{c.cm}$. human milk & $\begin{array}{l}\text { ", } \\
\text {, } \\
\text { ", }\end{array}$ & $\begin{array}{l}\text { ", } \\
\text { ", }\end{array}$ \\
\hline Group C. & Rachitogenic with $20 \mathrm{c.cm}$. human milk & $\begin{array}{c}\text { Marked } \\
\text { Moderate } \\
\text { ", } \\
\text { ", }\end{array}$ & $\begin{array}{c}\text { Marked } \\
\text { Moderate } \\
\text { ", } \\
\text { ", }\end{array}$ \\
\hline Group D. & Rachitogenic with 10 c.cm. buffalo's milk & $\begin{array}{c}\text { Absent } \\
\text {," } \\
\text {," }\end{array}$ & $\begin{array}{c}\text { Absent } \\
, " \\
" \\
"\end{array}$ \\
\hline Group E. & Rachitogenic with $\mathrm{CaPO}_{4}(0.3 \mathrm{grm})$. & $\begin{array}{l}\text { ", } \\
\text {, } \\
\text {, }\end{array}$ & $\begin{array}{l}\text { ", } \\
\text {," } \\
\text {, }\end{array}$ \\
\hline
\end{tabular}

which, according to them, is essential in any diet for the production of rickets. They found that human milk in quantities as large as $40 \mathrm{c.cm}$. daily was ineffective in curing rats from rickets, while $30 \mathrm{c.cm}$. of cow's milk daily brought about considerable healing. Hess and Weinstock used centrifugalized cow's cream (20 per cent. fat) which contains only a trace of phosphorus, and found that $8 \mathrm{c.cm}$. were needed to afford complete protection against rickets. Lesné and Vagliano ${ }^{7}$ using an ethereal extract of mother's 
TABLE 2.

ANTI-Rachitic Value of Fat IN hUman, cow's and bUfFalo's MiLK.

\begin{tabular}{|c|c|c|c|c|c|}
\hline \multirow[t]{2}{*}{ Rats. } & \multirow[t]{2}{*}{ Diet (4 weeks). } & \multicolumn{2}{|c|}{ Rickets. } & \multirow{2}{*}{\multicolumn{2}{|c|}{$\begin{array}{l}\text { Pooled blood } \\
\text { phosphorus. }\end{array}$}} \\
\hline & & X-rays. & Microscope. & & \\
\hline $\begin{array}{r}\text { Group A. } 1 \\
2 \\
3 \\
4 \\
5 \\
6\end{array}$ & Rachitogenic only & $\begin{array}{c}\text { Marked } \\
\text { Moderate } \\
\text { ", } \\
\text { ", }\end{array}$ & $\begin{array}{c}\text { Marked } \\
\text { ", } \\
\text { Moderate } \\
\text {," } \\
\text {," }\end{array}$ & $2 \cdot 6$ & rm. \% \\
\hline $\begin{array}{r}\text { Group B. } \\
2 \\
\mathbf{3} \\
4 \\
5 \\
6\end{array}$ & $\begin{array}{l}\text { Rachitogenic with } \\
4_{\%}^{\prime} \text { cow's milk fat }\end{array}$ & $\begin{array}{c}\text { Moderate } \\
\text { Marked } \\
\text { Moderate } \\
\text { ", } \\
\text { Marked }\end{array}$ & $\begin{array}{c}\text { Mcderate } \\
\text { Marked } \\
\text { Moderate } \\
\text { ", } \\
\text { Marked }\end{array}$ & $2 \cdot 1$ & " \\
\hline $\begin{array}{rr}\text { Group C. } & \\
& 2 \\
3 \\
4 \\
\\
5 \\
6\end{array}$ & $\begin{array}{l}\text { Rachitogenic with } \\
8 \% \text { cow's milk fat }\end{array}$ & $\begin{array}{c}\text { Moderate } \\
\text {,’ } \\
\text { Marked } \\
\text { Moderate } \\
\text { Marked } \\
-\end{array}$ & $\begin{array}{c}\text { Moderate } \\
\text { „” } \\
\text { Marked } \\
\text { Moderate } \\
\text { Marked } \\
-\end{array}$ & $\mathbf{2 \cdot 2}$ & $"$ \\
\hline $\begin{array}{r}\text { Group D. } 1 \\
2 \\
3 \\
4 \\
5 \\
6\end{array}$ & $\begin{array}{l}\text { Rachitogenis with } \\
12 \% \text { cow's milk fat }\end{array}$ & $\begin{array}{c}\text { Marked } \\
\text { Moderate } \\
\text {," } \\
\text { Marked } \\
\text { Moderate } \\
\text {," }\end{array}$ & $\begin{array}{c}\text { Marked } \\
\text { Moderate } \\
\text {," } \\
\text { Marked } \\
\text { Moderate } \\
\text {," }\end{array}$ & $\mathbf{2 \cdot 2}$ & " \\
\hline $\begin{array}{r}\text { Group E. } \\
\mathbf{2} \\
\mathbf{3} \\
\mathbf{4} \\
\mathbf{5} \\
\mathbf{6}\end{array}$ & \begin{tabular}{ccc}
\multicolumn{2}{c}{ Rachitogenie } & with \\
$4 \%$ human & milk \\
fat & &
\end{tabular} & $\begin{array}{c}\text { Moderate } \\
\text { Moderate } \\
\text { Moderate } \\
\text { Marked } \\
\text { Moderate } \\
\text { Marked }\end{array}$ & $\begin{array}{c}\text { Moderate } \\
\text { Mcderate } \\
\text { Moderate } \\
\text { Marked } \\
\text { Moderate } \\
\text { Moderate }\end{array}$ & $2 \cdot 7$ & , \\
\hline
\end{tabular}


TABLE 2-(contd.).

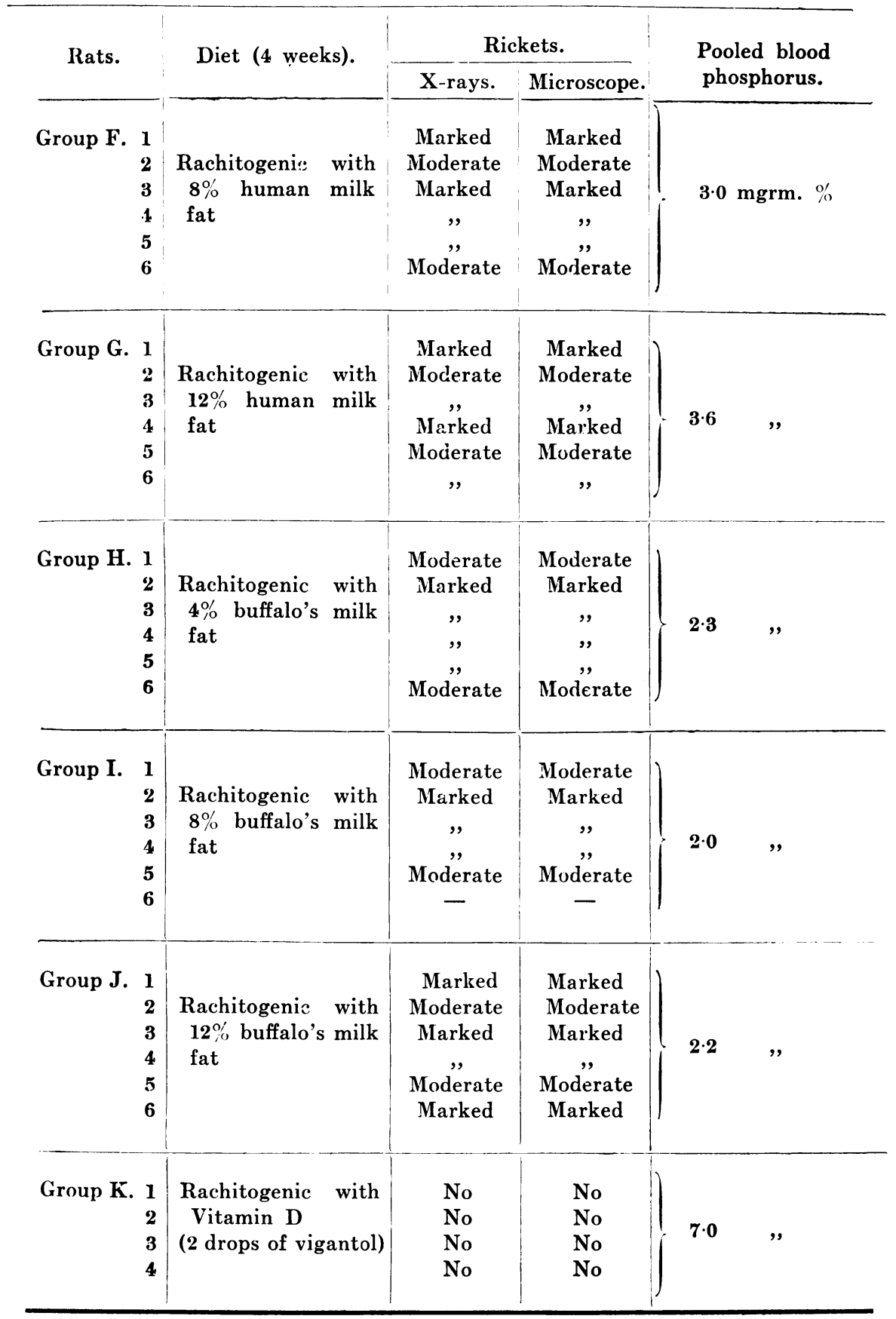


milk could not cure rickets in percentages up to 5 per cent. Kennedy and Palmer $^{8}$, experimenting with human milk fat, concluded that human milk fat could not cure rickets at a minimum level of 8 per cent. MacCollum and others ${ }^{9}$ showed that it is necessary to feed 15 to 30 per cent. of cow's butter fat to rats in order to bring about even a faint calcification of bones.

Experiments with milk fat.-In the following experiments we aimed at excluding the salt factor. We made butter from human milk of 80 wet nurses feeding healthy infants of the Foundling Home of Qasr el Aini Hospital and

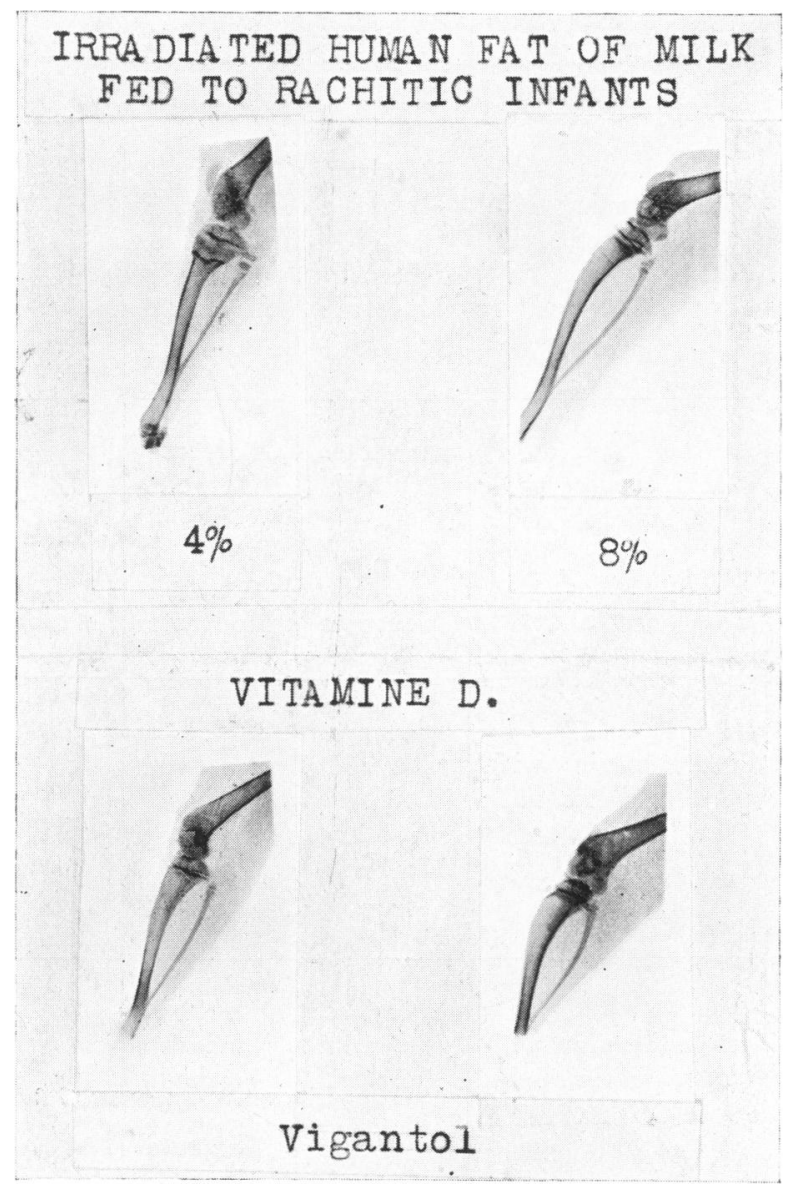

from buffalo's milk supplied to that hospital. Cow's milk butter was bought ready made from a reliable dairy. The butter obtained was heated in hot water baths kept constantly at $40^{\circ} \mathrm{C}$. till it changed to an oily consistency and all the remains of milk together with water and salts gravitated down. The fat obtained in this way was mixed with the Steenbock and Black rachitogenic diet (No. 2965) in increasing percentages. It was found that the addition of human, cow's and buffalo's milk fat to the rachitogenic diet 
in percentages up to 12 per cent. had no effect in preventing rickets. 'Addition of vitamin $D$ in minute doses ( 2 drops of Vigantol) could completely prevent the development of rickets (Table 2).

It thus becomes clear that vitamin D cannot be present in human, cow's or buffalo's milk fat in amounts of any value to prevent the development of rickets in rats.

\section{TABLE 3.}

ANTI-Rachitic Value of IRRAdiated MILK fat.

\begin{tabular}{|c|c|c|c|c|c|c|}
\hline \multirow[t]{2}{*}{ Rats. } & \multirow{2}{*}{\multicolumn{2}{|c|}{ Diet (4 weeks). }} & \multicolumn{2}{|c|}{ Rickets. } & \multirow{2}{*}{\multicolumn{2}{|c|}{$\begin{array}{l}\text { Pooled blood } \\
\text { phosphorus. }\end{array}$}} \\
\hline & & & X-rays. & Microscope & & \\
\hline Group A. 1 & $\begin{array}{l}\text { Rachitogenic with } 4 \% \\
\text { irradiated human } \\
\text { milk fat }\end{array}$ & 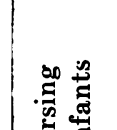 & $\begin{array}{l}\text { Slight } \\
\text { No }\end{array}$ & $\begin{array}{l}\text { Slight } \\
\text { No }\end{array}$ & 4.5 & grm. \% \\
\hline Group B. 1 & $\begin{array}{l}\text { Rachitogenic with } 8 \% \\
\text { irradiated human } \\
\text { milk fat }\end{array}$ & 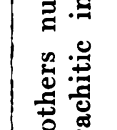 & , & ", & $5 \cdot 2$ & ", \\
\hline Group C. 1 & $\begin{array}{l}\text { Rachitogenic with } 12 \% \\
\text { irradiated human } \\
\text { milk fat }\end{array}$ & 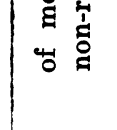 & " & " & $4 \cdot 6$ & ", \\
\hline Group D. 1 & $\begin{array}{l}\text { Rachitogenic with } 4 \% \\
\text { irradiated human } \\
\text { milk fat }\end{array}$ & 惫 & $\begin{array}{l}\text { Moderate } \\
\text { Moderate }\end{array}$ & $\begin{array}{l}\text { Moderate } \\
\text { Moderate }\end{array}$ & $4 \cdot 3$ & ", \\
\hline Group E. 1 & $\begin{array}{l}\text { Rachitogenic with } 8 \% \\
\text { irradiated human } \\
\text { milk fat }\end{array}$ & 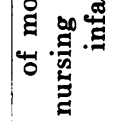 & $\begin{array}{l}\text { Slight } \\
\text {," }\end{array}$ & $\begin{array}{l}\text { Slight } \\
\text {, }\end{array}$ & 4.6 & ", \\
\hline Group F. 1 & $\begin{array}{l}\text { Rachitogenic with } 4 \% \\
\begin{array}{l}\text { irradiated } \\
\text { milk fat }\end{array}\end{array}$ & & $\begin{array}{l}\text { No } \\
\text {," }\end{array}$ & $\begin{array}{l}\text { No } \\
\text {, }\end{array}$ & $4 \cdot 8$ & , \\
\hline Group G. 1 & $\begin{array}{l}\text { Rachitogenic with } 8 \% \\
\text { irradiated } \\
\text { milk fat }\end{array}$ & & , & , & & - \\
\hline Group H. 1 & $\begin{array}{l}\text { Rachitogenic with } 12 \% \\
\text { irradiated cow's } \\
\text { milk fat }\end{array}$ & & , & ", & 4.5 & ", \\
\hline Group I. 1 & $\begin{array}{l}\text { Rachitogenic with } \\
\text { Vitamin D } \\
\text { (Vigantol 2 drops) }\end{array}$ & & ", & , & 4.8 & ," \\
\hline
\end{tabular}


Experiments with irradiated milk fat.-Although it is proved that milk, whatever its source, is poor in its vitamin-D content, it has been shown that irradiation of milk enhances its anti-rachitic power. Halac and Nassu ${ }^{10}$ have shown that a high anti-rachitic value is imparted to raw milk by a brief period of irradiation. Kramer ${ }^{11}$, Mackay and Shaw ${ }^{12}$, and György ${ }^{13}$ claimed to cure rickets in infants by irradiated milk. Supplee and Dow ${ }^{14}$ experimenting on rats with irradiated dry milk came to similar conclusions.

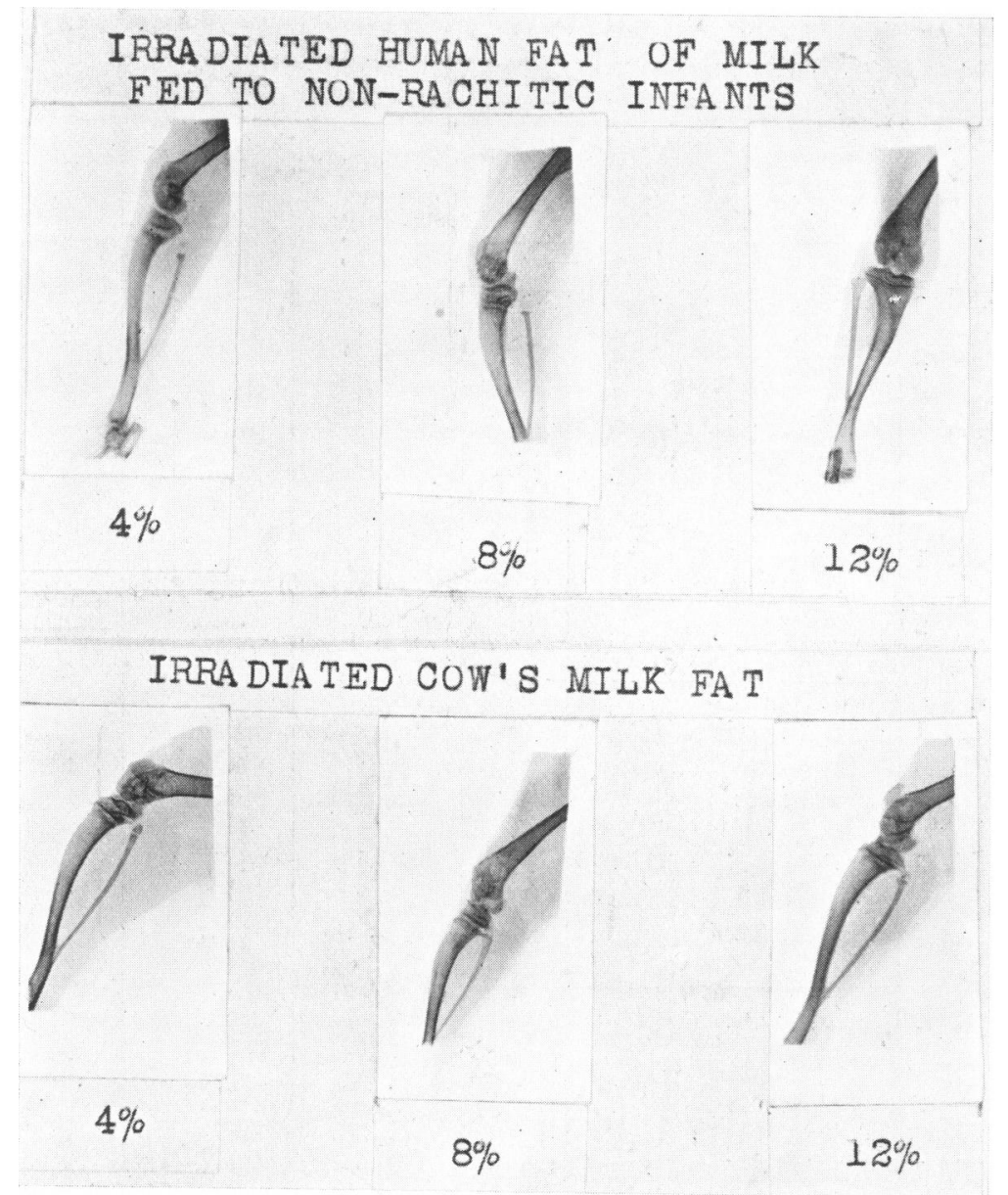

We obtained fat from the milk of a group of healthy women feeding healthy non-rachitic infants of an average age 6 to 12 months, and fat from the milk of another similar group of women nursing definitely rachitic infants of the same average age as the first group. In both groups, the infants were purely breast-fed, and were not, nor had been, suffering from gastrointestinal disturbance or infection of any note. The fat obtained in this way together with fat of cow's milk was irradiated by ultra-violet rays, then mixed with the rachitogenic diet in increasing percentages. 
The method of irradiation was to expose a layer of fat about $2 \mathrm{~mm}$. in depth at a distance of $30 \mathrm{~cm}$. from source of light for a period of 30 minutes.

It was found that irradiation of milk fat enhances markedly its antirachitic action. Thus while the addition of 12 per cent. non-irradiated fat to the rachitogenic diet could not prevent the development of rickets (see Table 2), addition of 4 per cent. irradiated milk fat could prevent the disease (Table 3).

Another interesting finding was that human milk fat of mothers nursing rachitic infants, even after irradiation, proved to be inferior in its anti-rachitic power to that of mothers feeding healthy non-rachitic infants.

\section{Summary of results.}

We may summarize the main results obtained from the above experiments as follows:-

(1) Human milk, cow's milk and buffalo's milk do not contain fully formed vitamin $D$ in amounts of any practical value in the prevention of rickets.

(2) The above milks contain a precursor of vitamin D (a provitamin) which on activation will be converted into vitamin $\mathbf{D}$ in amounts sufficient to prevent the development of rickets.

(3) Human milk of mothers feeding rachitic children is poorer in its content of this precursor of vitamin $\mathbf{D}$ than that of mothers nursing healthy non-rachitic children.

(4) There is no significant difference between human and cow's milk as regards their vitamin-D or provitamin content.

\section{Comment.}

The results of our experiments agree with those of most other workers in that milk, whatever its source, does not contain vitamin $\mathbf{D}$ in sufficient amounts to be of practical value in the prevention of rickets.

In addition, it has been shown by various workers that irradiation of milk endows it with anti-rachitic power. We came to a similar conclusion on irradiating milk fat itself. Thus, the child is evidently receiving in his milk supply sufficient amounts of the precursor of vitamin D (or provitamin) which will acquire anti-rachitic properties when irradiated by exposure of the child to sunlight or ultra-violet rays.

It has been shown also that rachitic children are probably receiving a smaller amount of provitamin in their milk supply.

The clinical difference between human and cow's milk in their antirachitic power which has been stated by various authors cannot be due to any difference in their vitamin-D or provitamin content, as both are present in nearly the same amounts in both milks. It must be ascribed to other factors. 
REFERENCES.

1. Mellanby, E., Med. Res. Coun., Lond., 1919, Sp. Rep., 38.

2. Hess, A. F., \& Weinstock, M., Am. J. Dis. Child., Chicago, 1927, XXXIV, 845.

3. Shawki, I., Rep. Internat. Cong. Trop. Med. \& Hyg., Cairo, 1928.

4. Marriot, W. M., Infant Nutrition, St. Louis, 1930, 67.

5. Marfan, A. B., Tr. de l'Allaitement et de l'Alimentation, Paris, 1930, 280.

6. Outhouse, J., Macy, I. G., \& Brekke, V., J. Biol. Chem., N.Y., 1928, LXXVIII, 129.

7. Lesne, E., \& Vagliano, M., Compt. Rend. Soc. de Biol., Paris, 1924, XCI, 143.

8. Kennedy, C., \& Palmer, L. S., Proc. Soc. Exp. Biol. \& Med., N.Y., 1925, XXIII, 230.

9. MacCollum, E. V., et al., J. Biol. Chem., N.Y., 1920-1, XLV, 333; 1922, LIII, 293.

10. Halac, E. S., \& Nassau, E., Ztschr. f. d. ges. phys. Therap., Berlin, 1925-6, XXXI, 153.

11. Kramer, B., Am. J. Dis. Child., Chicago, 1925, XXX, 195.

12. Mackay, H. M. M., \& Shaw, H. F., Brit. Med. J., Lond., 1925, ii, 344.

13. György, P., Klin. Wchnschr., Berlin, 1926, V, 747.

14. Supplee, G. C., \& Dow., O. D., Am. J. Child. Dis., Chicago, 1927, XXXIV, 364. 